\title{
URGENSI NILAI DAN MORAL SEBAGAI SUBTEORITIS PEMBELAJARAN PKn DI SD
}

\author{
Yayuk Kusumawati \\ Fakultas Syariah Institut Agama Islam Muhammadiyah Bima \\ Kampus: Jalan Anggrek No. 16, Ranggo Na'e \\ Email: yayukalkhansa@gmail.com
}

\begin{abstract}
Abstrak
Pendidikan kewarganegaraan merupakan salah satu mata pelajaran wajib yang diajarkan baik dari tingkat SD maupun perguruan tinggi sebagaimana tertuang dalam Undang-undang No. 20 Tahun 2003 tentang sistem pendidikan nasional pasal 3 menyatakan bahwa pedidikan nasional berfungsi mengembangkan kemampuan dan membentuk watak serta peradaban bangsa yang bermartabat dalam rangka mencerdaskan kehidupan bangsa. Hal ini pun tertuang dalam alinea ke empat di Pembukaan UUD 1945 yaitu mencerdaskan kehidupan bangsa, perlu penekanan pengetahuan agar generasi mampu berilmu baik itu terlihat dari cara berpikir maupun dari perbuatan, dan PKn menjadi mata pelajaran yang memiliki pesan-pesan nilai dan moral yang terkandung didalamnya salah satunya adalah pada mata pelajaran pembelajaran PKn di SD. Untuk mewujudkan yang diamanatkan oleh Pembukaan UUD 1945 di alinea ke empat maka perlu bantuan dari oknum yang akan mentarasnferkan pengetahuan tersebut dengan menjadi teladan bagi peserta didiknya yaitu seorang guru. Melalui seorang guru ini kemudian yang harus dilihat bagaimana dalam mengkristalisasikan nilai dan moral sebagai karakteristik pembelajaran PKn di SD dan ketika hal itu mampu dilaksanakan disitulah akan terlihat bahwa dalam pembelajaran PKn hadir untuk menanamkan nilai dan moral bagi generasi bangsa.
\end{abstract}

Kata Kunci: Nilai, Moral, Karakteristik Pembelajaran PKn SD

\section{PENDAHULUAN}

$\mathrm{P}$ endidikan sebagai bentuk dari jalan menuju mencerdaskan manusia yang membutuhkan ilmu pengetahuan sehingga dampaknya bisa terlihat dari bagaimana pola pikir dan tingkah laku berubah kearah yang positif, salah satu cara untuk mendapatkan ilmu pengetahuan melalui jalur pendidikan formal dan non-formal. Pendidikan formal bisa didapatkan dengan cara menempuh pendidikan melalui sekolah-sekolah, yaitu mulai dari tingkatan Sekolah Dasar (SD) sampai Perguruan tinggi. Pendidikan SD menjadi awal untuk membentuk peserta didik menjadi karakter yang memiliki nilai dan moral yang diharapkan oleh bangsa dan 
Negara, bahkan termuat materi khusus untuk peserta didik untuk membahas bagaimana menjadi warga Negara yang baik, penuh toleransi dan lain sebagainya yaitu melalui pelajaran Pendidikan Kewarganegaraan (Muhammad Erwin, 2013: 2).

Sebagaimana hal ini termuat dalam Undang-undang Sistem pendidikan No. 20 Tahun 2003 ditegaskan bahwa pendidikan adalah usaha sadar dan terencana untuk mewujudkan suasana belajar dan proses pembelajaran agar peserta didik secara aktif mengembangkan potensi dirinya untuk memiliki kekuatan spiritual keagamaan, pengendalian diri, kepribadian, kecerdasan, akhlak mulia serta keterampilan yang diperlukan dirinya, masyarakat, bangsa dan Negara. Lebih lanjut pasal 3 dikemukakan bahwa pedidikan nasional berfungsi mengembangkan kemampuan dan membentuk watak serta peradaban bangsa yang bermartabat dalam rangka mencerdaskan kehidupan bangsa. (Udin Winata Putra, 2014: 26).

Pendidikan harus memang diterapkan dengan cara pembudayaan sebagai proses pengembangan nilai dan moral dalam diri individu melalui proses perlibatan peserta didik dalam proses pendidikan yang merupakan bagian integral dari proses kebudayaan bangsa Indonesia, selanjutnya dapat ditekankan pula bahwa proses pembudayaan harus menuju kearah kemajuan dalam adab dan budaya persatuan Indonesia yang ber-Bhineka Tunggal Ika. Ditengah carut marutnya bangsa Indonesia sekarang dengan krisis pendidikan, krisis budaya dan bahkan degradasi nilai dan moral yang diharapkan oleh Negara untuk melahirkan generasi yang menjadi tombak penerus bangsa, menjadi harapan yang hampir nihil untuk diharapkan, dan bahkan bisa dikatakan dewasa sebelum waktunya untuk seusianya.Muncul keresahan seperti inilah kemudian yang coba digali dan kita tanamkan dalam pendidikan dengan memahamkan dan menerapkan pembelajaran PKn di SD yang diharapkan mampu untuk menciptakan karakter yang kuat akan nilai dan moral anak bangsa sejak dini.

\section{Nilai dan Moral dalam Pendidikan Kewarganegaraan}

Pendidikan nilai termasuk gagasan pendidikan yang mensosialisasikan dan menginternalisasikan nilai-nilai dalam diri siswa, sedangkan PKn SD merupakan mata pelajaran yang berfungsi sebagai pendidikan nilai-nilai pancasila dan budaya bangsa seperti yang terdapat pada kurikulum PKn SD (Kunawi Basyir, 2016: 21). Nilai pancasila yang digali dri bumi sendiri merupakan pandangan hidup dan panutan hidup bangsa Indonesia, dengan demikian nilai pancasila secara individu hendaknya 
dimaknai sebagai cermin perilaku hidup sehari-hari yang terwujud dalam cara bersikap dalam cara bertindak. Nilai pancasila bukanlah hanya sekedar kata-kata atau lembaran teks yang hanya dibaca melainkan terdapat nilai yang menjadi acuan dasar apalagi dalam hal pendidikan yang hasil akhirnya adalah bertujuan untuk mencerdaskan kehidupan generasi bangsa Indonesia.Nilai-nilai luhur ini termanifestasi dalam pancasila yang secara konstitusional dirumuskan dalam pembukaan UUD 1945 alinea ke empat (Trianto dan Titik, 2007:47).

Moral adalah ukuran baik buruk seseorang, baik sebagai pribadi maupun sebagai warga masyarakat dan warga Negara, seseorang dikatakan bermoral jika mematuhi maupun menjalankan aturan yang berlaku pada masyarakat.Undangundang dasar 1945 merupakan sumber motivasi dan aspirasi perjuangan dan tekad bangsa Indonesia. Pembukaan UUD 1945 juga merupakan sumber dari cita hukum dan cita moral yang ingin ditegakkan baik terhadap bangsa Indonesia sendiri maupun terhadap hubungan pergaulan antar bangsa-bangsa di dunia. (Arif Sukirman, 2006: 86). Konsepsi pendidikan nilai dan moral pieget yang menitikberatkan pada pengembangan kemampuan mengambil keputusan dan memecahkan masalah moral dalam kehidupan dapat diadaptasikan dan pendididkan nilai di Indonesia dalam konteks Bhineka tunggal ika.Konsepsi pendidikan nilai dan moral Kohlberg yang menitikberatkan pada penalaran moral melalui pendekatan klarifikasi nilai yang memberi kebebasan kepada individu peserta didik untuk memilih posisi moral, dapat digunakan dalam konteks keyakinan. (Udin Winata Putra, 2014: 26).

Dengan demikian hasil pembentukan sikap karakter anak pun dapat dilihat dari yaitu nilai dan moral, ketika spek ini diterapkan dengan baik dan benar maka hal tersebut akan nampak dalam sikap maupun kehidupan sehari-hari anak tersebut. Salah satu mata pelajaran yang menerapkaan ketiga aspek tersebut adalah pendidikan kewarganegaran dan hal ini bisa didapatkan dalam pendidikan formal karena dapat diyakini mampu memberikan nilai-nilai positif baik itu secara pengetahuan maupun perbuatan. Hal ini sesuai dengan pernyataan piaget bahwa pendidikan sekolah seyogyanya menitikberatkan pada pengembangan kemampuan mengambil keputusan dan memecahkan masalah dan membina perkembangan moral dengan cara menuntut para peserta didik untuk mengembangkan aturan berdasarkan keadilan. Pendidikan nilai berdasarkan teori pieget adalah pendidikan nilai moral atau nilai etis yang 
dikembangkan berdasarkan pendekatan psikologi pendekatan moral kognitif.Disitulah pendidikan nilai dititikberatkan pada pengembangan perilaku moral yang dilandasi oleh penalaran moral yang dicapai dalam konteks kehidupan masyarakat. (Udin Winata Putra, 2014: 49-50).

\section{Karkteristik Pembelajaran PKn Berdasarkan Nilai dan Moral}

PKn adalah pendidikan yang menyangkut status formal warga negara yang pada awalnya diatur dalam Undang-Undang No. 02 tahun 1949.Undang-Undang ini berisi tentang diri kewarganegaraan, dan peraturan tentang naturalisasi atau pemerolehan status sebagai warga negara Indonesia (Winarno, 2012: 30).

\section{Tujuan Pembelajaran PKn di SD}

a. Berpikir secara kritis, rasional, dan kreatif dalam menaggapi isu kewarganegaraan

b. Berpartisipasi secara aktif dan bertanggung jawab dan bertindak secara cerdas dalam kegiatan bermasyarakat, berbangsa dan bernegara serta anti korupsi

c. Berkembang secara positif dan demokratis untuk membentuk diri berdasarkan karakter-karakter masyarakat Indonesia agar dapat hidup bersama dengan bangsabangsa lainnya.

d. Berinteraksi dengan bangsa-bangsa lain dalam percaturan dunia secara langsung atau tidak langsung dengan memanfaatkan teknologi informasi dan komunikasi. (Udin Winataputra, 2014: 41).

Adanya pendidikan kewarganegaraan bagi bangsa Indonesia akan senantiasa diupayakan untuk membentuk manusia Indonesia seutuhnya, sebagaimana diamanatkan pembukaan UUD 1945 yakni sebagai manusia Indonesia yang religius, berkemanusiaan dan berkeadaban, yang memiliki nasionalisme, yang cerdas, yang berkerakyatan dan yang adil terhadap lingkungan sosialnya. (Muhammad Erwin, 2013: 6). Sejalan dengan hal tersebut, menurut Mulyasa dalam Ahmad Susanto mengungkapkan bahwa tujuan mata pelajaran pendidikan kewarganegaraan adalah untuk menjadikan siswa sebagai berikut:

a. Mampu berfikir secara kritis, rasional, dan kreatif dalam menanggapi persoalan hidup maupun isu kewarganegaraannya.

b. Mampu berpartisipasi dalam segala bidang kegiatan, secara aktif dan bertanggung jawab, sehingga dapat bertindak secara cerdas dan semua kegiatan. 
c. Mampu berkembang secara positif dan demokratis, sehingga dapat hidup bersama dengan bangsa lain di dunia dan mampu berinteraksi, serta mampu memanfaatkan teknologi inforamasi dan komunikasi dengan baik. Hal ini mudah tercapai jika pendidikan nilai dan norma tetap ditananmkan padasiswa sejak usia dini, karena jika siswasudah memiliki nilai norma yang baik, maka tujuan untuk mencapai warga negaran yang baik akan mudah terwujudkan. (Ahmad Susanto, 2013: 231).

Berdasarkan tujuan pembelajaran PKn SD diatas dapat dikemukakan bahwa pembelajaran PKn dapat disebut sebagai pendidikan yang berkaitan dengan konsep nilai, moral dan norma karena memang pendidikan kewarganegaarn merupaakan mata pelajaran yang memperhatikan bagaimana menjadi warga Negara yang baik maka dari itu perlu adanya pembahasan tentang nilai dan moral agar sikap dan karakter siswa yang diharapkan menjadi generasi penerus bangsa yang cerdas bisa terwujud. Untuk membedakan mata pelajaran PKn dengan matakuliah lain maka perlu adanya indikator dalam penentuan yang menjadi ciri khas dari mata pelajaran itu sendiri, salah satunya adalah karakteristik yang akan dibahas.

\section{Karakteristik Pendidikan Kewarganegaraan (PKn)}

a. PKn termasuk dalam proses ilmu sosial (IPS).

b. PKn diajarkan sebagai mata pelajaran wajib dari seluruh program sekolah dasar sampai perguruan tinggi.

c. PKn menanamkan banyak nilai, diantaranya nilai kesadaran, bela negara, penghargaan terhadap Hak Asasi Manusia, pelestarian lingkungan hidup, tanggung jawab sosial, ketaatan pada hukum, ketaatan membayar pajak, serta sikap dan perilaku anti korupsi, kolusi, dan nepotisme.

d. PKn memiliki ruang lingkup meliputi aspek Persatuan dan Kesatuan bangsa, norma, hukum, dan peraturan, Hak Asasi Manusia, kebutuhan warga negara, Konstitusi Negara, Kekuasan dan Politik, Pancasila dan Globalisasi.

e. PKn memiliki sasaran akhir atau tujuan untuk terwujudnya suatu mata pelajaran yang berfungsi sebagai sarana pembinaan watak bangsa (nation and character building) dan pemberdayaan warga negara.

f. PKn merupakan suatu bidang kajian ilmiah dan program pendidikan di sekolah dan diterima sebagai wahana utama serta esensi pendidikan demokrasi di Indonesia. 
g. PKn mempunyai 3 pusat perhatian yaitu Civic Intellegence (kecerdasan dan daya nalar warga negara baik dalam dimensi spiritual, rasional, emosional maupun sosial), Civic Responsibility (kesadaran akan hak dan kewajiban sebagai warga negara yang bertanggung jawab), dan Civic Participation (kemampuan berpartisipasi warga negara atas dasar tanggung jawabnya, baik secara individual, sosial maupun sebagai pemimpin hari depan).

h. PKn lebih tepat menggunakan pendekatan belajar kontekstual untuk mengembangkan dan meningkatkan kecerdasan, keterampilan, dan karakter warga negara Indonesia. Contextual Teaching and Learning (CTL) merupakan konsep belajar yang membantu guru mengaitkan antara materi yang diajarkan dengan situasi dunia nyata siswa dan mendorong siswa membuat hubungan antara pengetahuan yang dimilikinya dengan penerapannya dalam kehidupan mereka sehari-hari.

i. PKn mengenal suatu model pembelajaran VCT (Value Clarification Technique/Teknik Pengungkapan Nilai), yaitu suatu teknik belajar-mengajar yang membina sikap atau nilai moral (Ali Mustofa dan Irfan Tamwifi, 2009: 43).

Dari karakteristik yang ada, terlihat bahwa PKn merupakan mata pelajaran yang memiliki karakter berbeda dengan mata pelajaran lain. Keberadaan PKn dengan karakteristik seperti ini mestinya menjadi perhatian besar bagi masyarakat, komponen pendidik dan negara.Hal ini disebabkan karena PKn banyak melanggar nilai-nilai pada siswanya. Nilai-nilai kebaikan kebersamaan, pengorbanan, menghargai orang lain dan persatuan ini jika di tanamkan dalam diri siswa bisa menjadi bekal yang sangat berharga dalam kehidupan pribadi maupun berbangsa dan bernegara.

\section{Pendidikan Nilai dan Moral Dalam Ruang Lingkup Standar Isi PKn}

Ruang lingkup PKn sekolah samadari mulai SD, SMP, dan SMA.Pembedanya adalahpada penjabaran yang ditekankan, kedalaman, dan keluasan ruang lingkup itu disesuaikan dengan tingkat sekolah. Menurut, pandangan Musthafa Kamal Pasha (2009) Perwujudan selanjutnya adalah pada masing-masing Standar Kompetensi (SK) dan Kompetensi Dasar (KD) yang ada. Sehubungan dengan hal tesebut, Rumusan SK-KD sesungguhnya secara implisit telah menampilkan ruang lingkup materi ajar apa yang hendak diajarkan dan ranah belajar yang mana yang hendak diajarkan. 
Ruang lingkup meliputi delapan substansi kajian, sedangkan materi belajar merupakan jabaran dari ruang lingkup yang secara implisit termuat dalam rumusan Standar Kompetensi (SK) dan Kompetensi Dasar (KD).

Ruang lingkup dan materi pembelajaran PKn MI sebagaimana yang dinyatakan pada kurikulum Nasional yang tercantum dalam Permen 22/2006 tentang Standar Isi adalah sebagai berikut:

1. Persatuan dan Kesatuan bangsa, meliputi hidup rukun dalam perbedaan, cinta lingkungan, kebanggaan sebagai bangsa Indonesia, sumpah pemuda, keutuhan Negara Kesatuan Republik Indonesia, partisipasi dalam pembelaan negara, sikap positif terhadap Negara Kesatuan Republik Indonesia, keterbukaan dan jaminan keadilan.

2. Norma, hukum, dan Peraturan, meliputi tertib dalam kehidupan keluarga, tata tertib di sekolah, norma yang berlaku di masyarakat, peraturan-peraturan daerah, norma-norma dalam kehidupan berbangsa dan bernegara, sistem hukum dan peradilan nasional, dan hukum peradilan internasional.

3. Hak Asasi Manusia, meliputi hak dan kewajiban anak, hak dan kewajiban anak, hak dan kewajiban anggota masyarakat, instrument nasional dan internasional HAM, pemajuan, penghormatan dan perlindungan HAM.

4. Kebutuhan Warga negara, meliputi hidup gotong royong, harga diri sebagai warga masyarakat, kebebasan berorganisasi, kemerdekaan mengeluarkan pendapat, menghargai keputusan bersama, prestasi diri, persamaan kedudukan warga negara.

5. Konstitusi Negara, meliputi proklamasi kemerdekaan dan konstitusi yang pertama, konstitusi-konstitusi yang pernah digunakan di Indonesia, hubungan dasar negara dengan konstitusi.

6. Kekuasaan dan Politik, meliputi pemerintahan desa dan kecamatan, pemerintahan daerah dan otonomi-pemerintahan pusat, demokrasi dan sistem politik, budaya politik, budaya demokrasi menuju masyarakat madani, sistem pemerintahan, pers dalam masyarakat demokrasi.

7. Kedudukan Pancasila, meliputi kedudukan Pancasila sebagai dasar negara dan ideologi negara, proses perumusan pancasila sebagai dasar negara, pengalaman 
nilai-nilai pancasila dalam kehidupan sehari-hari, Pancasila sebagai ideologi terbuka.

8. Globalisasi, meliputi globalisasi di lingkungannya, politik luar negeri Indonesia di era globalisasi, dampak globalisasi, hubungan internasional dan organisasi internasional, dan mengevaluasi globalisasi. (Basyir Kunawi, 2016: 27).

Dalam standar isi diruang lingkup PKn diatas terlihat jelas bahwa memang mengandung nilai dan moral yang tercermin dalam setiap judul pembahasan pendidikan kewarganegaraan, maka kemudian hal ini perlu penyampaian dari tenaga pendidik yaitu guru yang mampu untuk mentransferkan ilmu dan menjadi teladan yang baik untuk mencapaian penanaman nilai dan moral yang terdapat didalamnya.

\section{Upaya Guru Dalam Menanamkan Nilai Dan Moral Pada Peserta Didik}

Undang-undang dasar 1945 sebagai landasan konstitusional pada bagian pembukaan alineaa keempat memberikan dasar pemikiran tentang tujuan Negara. Salah-satu tujuan Negara tersebut dapat dikemukakan dari pernyataan "mencerdaskan kehidupan bangsa" (Muhammad Erwin, 2013: 7). Pesan yang disampaikan dalam alinea ke empat secara jelas menginginkan bahwa generasi bangsa Indonesia mampu berpikir dengan baik dan benar, dan ketika hal ini terwujud maka perilaku maupun sikap akan tercerminkan dalam kehidupan sehari-hari. Secara yuridis dan legalitas hukum bahwa cerminan pendidikan nilai dan moral di Indonesia dilaksanakan melalui pendidikan kewarganegaraan yang berlandaskan pada Undang-undang No. 20 Tahun 2003 tentang sistem pendidikan nasional (SISDIKNAS) sebagai landasan operasional (Zainul Ittihad, 2009: 6). Pendidikan karakter yang berpijak pada sebuah pemikiran bahwa ada seperangkat kebajikan sepeti kejujuran, budi baik, kesabaran, ketegaran yang menjadi landasan perilaku moral, oleh karena itu ditegaskannya bahwa tugas guru adalah membelajarkan kebajikan itu melalui percontohan dan komunikasi langsung keyakinan serta menfasilitasi peserta didik untuk melaksanakan kebajikan itu dengan memberinya penguatan.

Mutmayani Andryan dkk., (2013: 44) menjelaskan bahwa untuk memberikan pengutan tersebut bahwa mengenal dan memahami karakter anak itu penting setiap individu memiliki empat dasar mental yaitu meliputi dorongan ingin tahu (sense of curiosity), minat (sense of interest), dorongan ingin melihat (sense of reality), dorongan menemukan sendiri hal-hal dan gejala-gejala dalam kehidupan (sense of 
discovery). Dasar mental tadi merupakan modal yang sangat berharga bagi pelaksanaan dan penyelenggaran pendidikan. Oleh karena itu, harus dipupuk dan dikembangkan secara positif bagi kepentingan anak sendiri.Selanjutnya sebagai anggota masyarakat, dasar mental yang dimiliki harus dibina ke arah tanggungjawab anak tersebut sebagai insan sosial.Kewajaran kehidupan mereka dapat dikatakan normal, bila dasar mental mereka serasi dengan kondisi dan situasi kehidupan sosialnya. Sehingga untuk menanamkan Pembelajaran Pkn yang berbasis nilai dan moral tergantung bagaimana metode guru dalam mengajar seperti bernyanyi, bercerita atau dalam bentuk permainan edukasi, dari sini lah kemudian bisa kita lihat

sejauh mana guru mampu mengelola kelas dan peserta didik mampu ditanamkan nilai dan moral tersebut melalui pembelajaran PKN di SD dan tetntunya guru harus menjadi tokoh utama yang memberikan contoh dan teladan yang baik bagi peserta didiknya. Apa yang disampaikan itu yang dilakukan artinyailmu yang diberikan sesuai dengan perilaku guru tersebut.

\section{SIMPULAN}

Menyelamatkan generasi bangsa dari degradasi nilai dan moral untuk saat sekarang adalah suatu keharusan yang perlu diperhatikan dalam semua kalangan tidak hanya menjadi tugas dan kewajiban seseorang yang berlabel guru, akan tetapi dari lingkungan keluarga dan masyarakat ikut membantu sehingga generasi yang diharapkan oleh Negara sebagai tombak bangsa terwujud. Salah satu cara untuk mewujudkan harapakan bangsa tersebut adalah dengan mengikuti pendidikan formal yang disiapkan oleh Negara yaitu sekolah dari sinilah penanaman pengetahuan dan sikap yang baik berakar mulai dari SD dengan adanya mata pelajaran pembelajaran PKn di SD yang memiliki karakteristik yang unik dari mata pelajaran lainnya salah satunya merupakan penjewantahan dari pendidikan nilai dan moral. Upaya pengembangan nilai, moral dan sikap diharapkan dapat menjadikan seseorang menjadi individu yang diharapkan yakni melalui penciptaan komunikasi serta penciptaan iklim lingkungan yang serasi. 


\section{DAFTAR PUSTAKA}

Erwin, Muhammad. 2013. Pendidikan Kewarganegaraan Republik Indonesia.Bandung : PT Refika Aditama

Ittihad, Zainul. 2009. Pendidikan Kewarganegaraan. Jakarta : Universitas Terbuka

Kamal Pasha, Musthafa. 2007. Pendidikan Kewarganegaraan. Yogyakarta : Citra Karta Mandiri

Kunawi, Basyir, dkk. 2016. Pancasila dan Kewarganegaraan. Surabaya: UIN SA Press

Mustofa, Ali dan Irfan Tamwifi. 2009. Materi Pembelajaran IPS/PKN MI. Surabaya:UINSA

Mutmayani, Andryan., dkk. 2013. Perkembangan Peserta Didik Perkembangan Moral Nilai dan Sikap. Jakarta : PT Press Media

Sukirman, Arif. 2006. Pengantar Pemahaman Ideologi. Yogyakarta: Lengge Printika.

Susanto, Ahmad. 2013. Teori Belajar dan Pembelajaran di Sekolah Dasar. Jakarta: Kencana Prenada Media Group.

Trianto dan Titik, 2007. Falsafah Negara dan Pendidikan Kewarganegaraan.Jakarta : Prestasi Pustaka.

Winarno. 2012. Pembelajaran Pendidikan Kewarganegaraan. Jakarta: PT Bumi Aksara.

Winataputra, Udin. 2014. Pembelajaran PKn di SD. Universitas terbuka :Tangerang 